La "liberación" del Campo de Concentración de Castuera: rebelarse a través del espacio

Sergio González García

páginas / año $9-n^{\circ} 21$ Septiembre-Diciembre / ISSN 1851-992X/ pp. 11-33 /

2017

http://revistapaginas.unr.edu.ar/index.php/RevPaginas

\title{
La 'liberación' del Campo de Concentración de Castuera: rebelarse a través del espacio
}

\section{Castuera Concentration Camp 'liberation': a rebelion through the space}

\author{
Sergio González García \\ Universidad Complutense de Madrid, \\ Grupo de Investigación de la Universidad Complutense de Madrid "Espacio \\ y poder" (GIEP), España \\ segonz01@ucm.es
}

\begin{abstract}
Resumen
Castuera es un municipio de la provincia de Badajoz, en la Extremadura española, cuya historia no puede escapar de la existencia en su territorio, a finales de los años treinta, de un Campo de Concentración. La existencia de este campo y la evolución de sus restos, una vez desmantelado, permiten ver cómo el control y la violencia ejercida por el régimen franquista en España tras el fin de la Guerra Civil no sólo se impuso a través de la represión sistemática sino también por medio del dominio del espacio público. En este artículo se va a considerar fundamental el proceso por el cual el franquismo trató de imponer una forma de usar el espacio público y de controlar el relato del pasado a través de las marcas, materialidades y rituales que resultaban aceptables en el mismo y aquellas que eran proscritas. El proceso de democratización trató de pacificar este dominio por medio de la imposición de una narrativa de consenso y superación, la cual se vería alterada por una práctica concreta que se rebelaría contra este espacio y discurso hegemónico: la marcha de homenaje al campo de concentración.
\end{abstract}

\section{Palabras claves}

Espacio; Memoria; Campo de Concentración; Práctica; Contrahegemonía.

\footnotetext{
Abstract

Castuera is a town in Badajoz province, in Extremadura (Spain), whose history can't scape of the existence of a Concentration Camp in its territory at the end of the thirties. This camp and the evolution of its ruins, when it was dismantled, allows to see how the francoist Esta obra está sujeta a la Licencia Reconocimiento-NoComercial-CompartirIgual 4.0 Internacional de Creative Commons. http://creativecommons.org/licenses/by-nc-sa/4.0/

(cc) EY-NC-SA
} 


\section{La 'liberación' del Campo de Concentración de Castuera: rebelarse a través del espacio}

control and violence after the end of Spanish Civil War not only was imposed through repression but also by the public space control. In this article, the process by which the francoist regime tried to impose a way to use the public space and control the narrative of the past through marks, materialities and rituals which were acceptables and which were forbidden, is going to be considered as fundamental. The democratization process tried to pacify this control by the imposition of a narrative of consensus and overcoming, which was altered by a specific practice that would rebel against this space and hegemonic narrative: the commemoration march to the concentration camp.

Keywords

Space; Memory; Concentration Camp; Practice; Counterhegemony.

\section{La importancia de la relación entre espacio y memoria}

Anualmente, durante el mes de Abril y en fechas cercanas -según la disponibilidad del calendario- a la conmemoración del 14 de Abril -día de proclamación de la II República española- la Asociación Memorial Campo de Concentración de Castuera (AMECADEC) organiza un fin de semana de actividades en torno a la recuperación de la memoria y como proyección de las demandas del movimiento memorialista en Extremadura y a nivel Estatal. Dichas jornadas, que suelen ocupar tres días, están compuestas por charlas, visionado de documentales y, por último, la organización de una marcha de homenaje desde el municipio hasta los cercanos restos del Campo de Concentración. Esta práctica, anual y conmemorativa, recorre los pasos que realizaban los presos de posguerra por el municipio hasta llegar al campo. La finalidad pasa por el homenaje y actualización de ese relato del pasado y por, fundamentalmente, dar visibilidad a una memoria colectiva que durante años estuvo privatizada y a una forma de entender el espacio público diferente a la hegemónica que viene a señalizar lugares emblemáticos en el municipio vinculados con el recuerdo y el homenaje. La finalidad simbólica para los organizadores se centra en recordar, reparar y "liberar" simbólicamente el campo de concentración. Por lo tanto, supone una práctica que debe entenderse como una rebelión contra el discurso memorial imperante, que como se verá tiene elementos que se mantienen desde el franquismo, y contra una concepción del municipio únicamente vinculado a lo rural, lo agrícola y lo artesanal.

Como las ideas anteriores esbozan, la investigación de la que parte este artículo ha tomado en consideración la necesidad de entender la relación entre el proceso de producción del espacio y la configuración de los relatos sobre el pasado. Se ha entendido que memoria y espacio se entrelazan en una compleja red de prácticas, significados y discursos que se deben analizar con detenimiento para entender cómo y con qué objetivo se produce el espacio o se señalizan lugares emblemáticos en el mismo. Estos lugares, en este caso el Campo de Concentración 


\section{Sergio González García}

de Castuera, deben ser entendidos como procesos conflictivos sometidos a una disputa constante entre relatos e imaginarios contrapuestos que los señalizan -o los relegan- y los dotan de significados diferenciados. Así, lo fundamental está en entender que los lugares están en constante elaboración y que la memoria está espacialmente constituida viéndose ésta reflejada en el espacio y existiendo a su vez una memoria del mismo. Por lo tanto, este artículo asume la idea de Karen Till que expone que los grupos piensan el pasado como una forma de conocimiento espacial de su mundo al mismo tiempo que fijan éste en el espacio como una forma de apropiación, uso y control del mismo estableciendo que la memoria se conforme como una relación espacio temporal ${ }^{1}$.

Partiendo de esta idea, el espacio actúa como un elemento a partir del cual los grupos se disputan los relatos del pasado y ponen en juego su identidad ${ }^{2}$. Así la resistencia, y las prácticas de rebeldía asociadas a la misma, se espacializan, tal y como la marcha de homenaje que se realiza anualmente en Castuera nos permite ver. Espacialización de las resistencias y de las memorias que muestra la conflictividad ligada a la existencia de memorias débiles y fuertes ${ }^{3}$, oficiales y subalternas, hegemónicas y contrahegemónicas que se relacionan con formas diferenciadas de concebir, entender, usar y vivir el espacio. De esta manera, la resistencia aparece desde un contraespacio cargado de una contramemoria que entra en disputa con los intentos de imponer una memoria oficial y de pacificar el espacio a través de las que Meyer ha denominado politics of history4.

Entendiendo que la configuración de los relatos del pasado, las memorias que se convierten en fuertes, y la concepción del espacio oficial responden a decisiones políticas e ideológicas y no a meros procesos técnicos, será desde los espacios de la experiencia cotidiana, donde las memorias colectivas se configuren ligadas al espacio vivido, desde donde aparecerá la impugnación y las prácticas de rebeldía. Un conjunto de relaciones entre la concepción y la vivencia del espacio a través de prácticas diferenciadas (planes, proyectos, manifestaciones, marchas,...) que se pueden apreciar siguiendo los planteamientos de Henri Lefebvre5. Planteamientos que exponen la necesidad de entender la totalidad del espacio, analizando por lo tanto tres momentos en constante relación, el espacio concebido de los técnicos, urbanistas e instituciones que pretende dar apariencia neutral y objetiva a sus decisiones normativas, el espacio vivido ligado a la vida cotidiana y la experiencia diaria que marca determinados lugares y dota de significados y valores al mismo, y, por último, el espacio percibido que se materializa a través de las prácticas a través

\footnotetext{
${ }^{1}$ Karen Till. "Emplacing memory through the city: the New Berlin". GHI Bulletin, №35, 2004, p.76

2 Karen Till. "Places of memory" en J. Agnew, K. Mitchel y G. Toal, A companion of Political Geography, Londres, Blackwell Publishing Company, 2003, p.295.

3 Enzo Traverso. El pasado, instrucciones de uso. Historia, memoria, política. Madrid-Barcelona, Marcial Pons, 2007, p.48.

4 Erik Meyer. "Memory and politics" en A. Erll y A. Nünning (eds.), Memory Studies: And International and Interdisciplinary Handbook, Berlin, Walter de Gruyter, 2008, p.176.

${ }^{5}$ Henri Lefebvre. La producción del espacio. Madrid, Capitán Swing Libros, 2013 (1974).
} 


\section{La 'liberación' del Campo de Concentración de Castuera: rebelarse a través del espacio}

de las cuales la concepción y la vivencia entran en disputa 6 . Así, entendiendo ese conflicto, entre el espacio concebido por el franquismo, con extensión en la etapa democrática, y la vivencia del mismo, se podrá analizar que la marcha del homenaje en Castuera no sólo señalizará el campo de concentración y lo hará visible sino que, por un lado, aparecerá como forma de materializar una forma concreta de vivir el espacio opuesta a los reconocimientos institucionales $\mathrm{y}$, por otro lado, definirá un nuevo espacio desde la memoria que había sido silenciada y sus lugares emblemáticos.

\section{El campo de concentración en Castuera: una pequeña introducción}

El municipio de Castuera se encuentra en la comarca de La Serena, una amplia región de la provincia de Badajoz en España. La Guerra Civil marcaría al pueblo no sólo por la importancia estratégica que tendría durante la contienda sino también por la ubicación en el mismo de estructuras de represión franquistas que influirían su evolución histórica. Una de estas estructuras represivas, se podría decir que la fundamental por los efectos que tuvo sobre el municipio y sobre toda la región, fue el Campo de Concentración que se instaló a las afueras del casco urbano.

Los restos del Campo de Concentración que quedaron una vez que éste fue desmantelado en 1940 han supuesto en estos últimos años un punto de reclamación y demanda de recuperación de la memoria ante el proceso de obliteración ${ }^{7}$ impuesto tanto durante la dictadura como en el período democrático. Esto ha dado lugar a una disputa entre el relato del pasado del municipio vinculado a la represión y al miedo creado por el franquismo, la visión del mismo desde la óptica de la superación del pasado, la neutralidad y el olvido y la recuperación de la memoria dentro de un discurso de homenaje, reparación y defensa de los Derechos Humanos. Posiciones que han derivado en prácticas y construcción de imaginarios y relatos contrapuestos dentro de una situación durante la etapa democrática de hegemonía del Partido Socialista Obrero Español (PSOE) en el gobierno municipal.

El Campo fue construido en los momentos finales de la guerra para ser lugar de encarcelamiento y clasificación del alto volumen de prisioneros republicanos tras la toma de la región por parte de las tropas franquistas. Las instalaciones represivas del Campo de Concentración estaban situadas a una distancia prudencial del casco urbano del municipio para mantenerse lejos de cualquier tipo de intromisión incómoda o indiscreta ${ }^{8}$ por parte de vecinos y transeúntes pero a su vez en un espacio lo suficientemente limítrofe al mismo que permitía proyectar la presencia simbólica represiva del campo dentro del pueblo. Además, dicha

\footnotetext{
6 Ídem, p.100-102.

${ }^{7}$ Kenneth Foote. Shadowed Ground. America's Landscapes of Violence and Tragedy. Austin (Texas), University of Texas, 1997, p. 24-27.

${ }^{8}$ Guillermo León Cáceres, Antonio Rodríguez López, et al. "El Campo de Concentración de Castuera: del olvido forzado a lugar de memoria y recurso didáctico". Revista de Estudios Extremeños, Vol. LXVII, № 2, Badajoz, 2011, p. 539.
} 


\section{Sergio González García}

presencia se veía reforzada por la existencia en el casco urbano de lugares vinculados a la represión como eran diversos establecimientos penitenciarios desde los que se establecía una conexión directa con el Campo a través de las cuerdas de presos. El principal acceso al Campo de Concentración durante su actividad y a los restos actuales del mismos discurre por un camino que pasa al lado del cementerio municipal, lugar vinculado estrechamente a la represión y a los asesinatos extraoficiales de las llamadas 'sacas' falangistas.

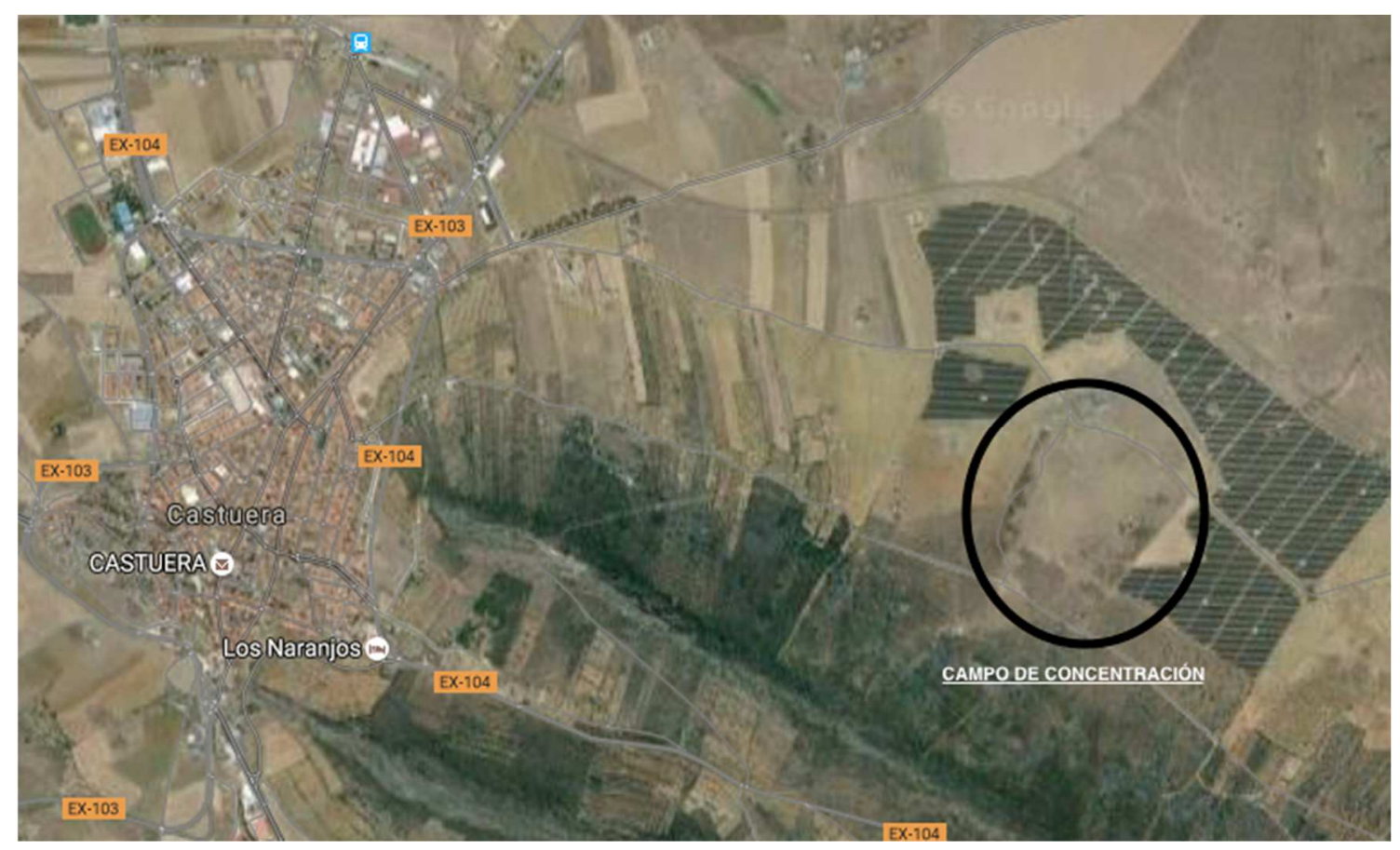

Mapa 1: Ubicación del Campo de Concentración de Castuera. Fuente: Elaboración propia a partir de imagen de Google (Imágenes @2016 Cnes/Spot Image, Digital Globe, Instituto de Cartografía de Andalucía, Landsat, Datos del Mapa @2016 Google, Inst. Geogr. Nacional).

Las instalaciones del campo contaban con un conjunto de barracones alineados a lo largo de ocho calles con una plaza central presidida por una cruz donde se realizaban actos, conmemoraciones y misas de obligada asistencia. También contaba con una zona de letrinas, lavaderos, zona de incomunicados, una bandera en la zona exterior, como elemento simbólico del control efectivo del territorio por parte del franquismo, y la casa del jefe del Campo 9 .

\footnotetext{
${ }^{9}$ Antonio López Rodríguez. Cruz, bandera y caudillo. El Campo de Concentración de Castuera. Badajoz, CEDER-La Serena, 2006, p.191.
} 


\section{La 'liberación' del Campo de Concentración de Castuera: rebelarse a través del espacio}

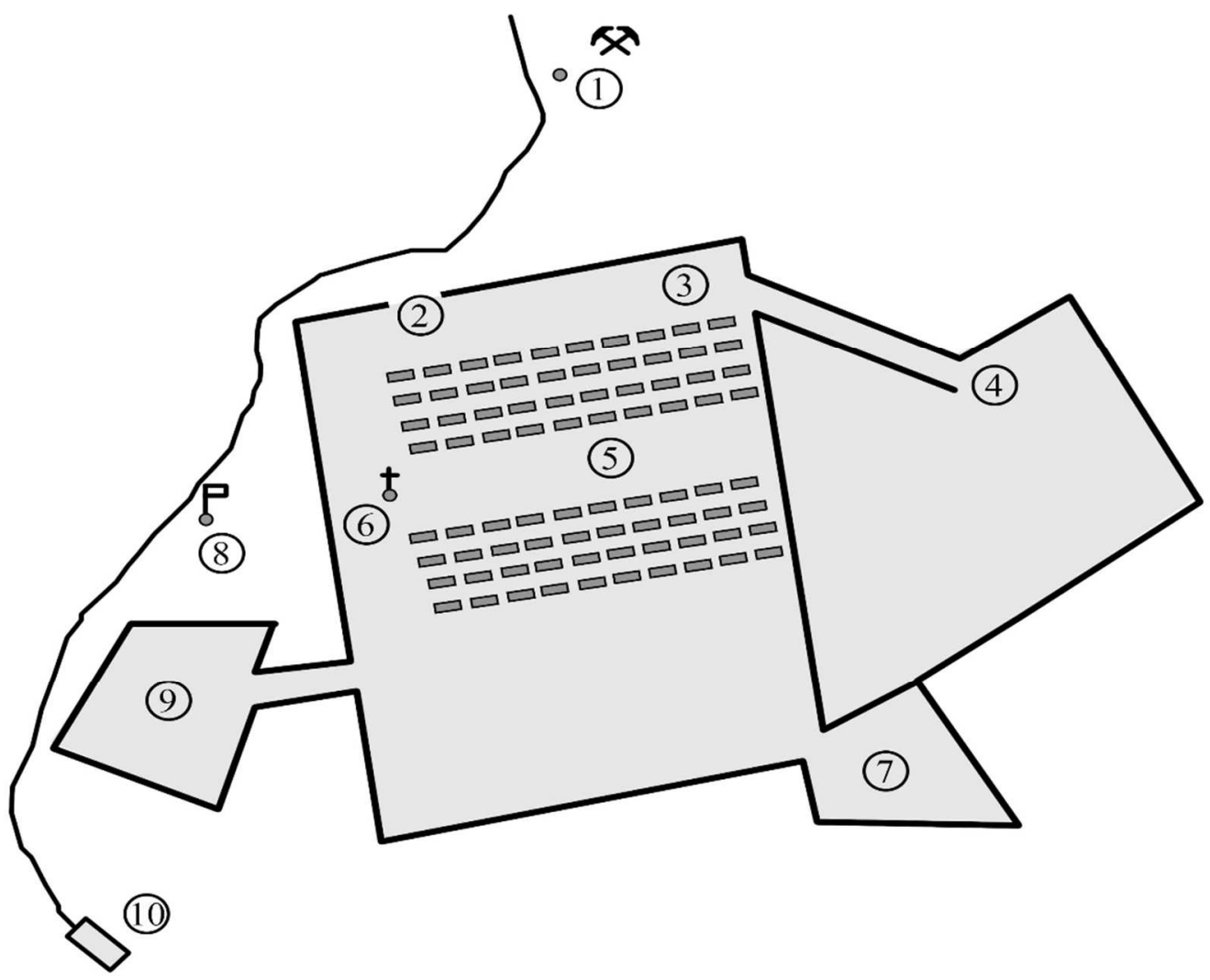

Mapa 2: Mapa del Campo de Concentración de Castuera con dependencias señaladas: 1. Mina de La Gamonita. 2. Entrada principal al campo. 3. Barracones. 4. Letrina. 5. Patio central. 6. Cruz. 7. Lavaderos. 8. Bandera. 9. Zona de incomunicados. 10. Casa del Jefe del Campo. Fuente: Elaboración propia a partir de imágenes en José Ramón González Cortes, Guillermo León Cáceres, et al. Catálogo de la Exposición 'El sistema de Campos de Concentración franquistas, el campo de concentración de Castuera'. Castuera, AMECADEC, 2009 y Guillermo León Cáceres, Antonio Rodríguez López, et al. "El Campo de Concentración de Castuera: del olvido forzado a lugar de memoria y recurso didáctico". Revista de Estudios Extremeños, Vol. LXVII, № 2, Badajoz, 2011.

Instalaciones que crearían una atmósfera de represión, arbitrariedad y terror a través de los asesinatos por medio de las "sacas" falangistas, las palizas, los periodos de incomunicación y todo el proceso de aniquilación y exterminio en búsqueda de esa "cura" del cuerpo social que pretendía la dictadura10. Represión unida a unas condiciones de vida caracterizadas por el hambre, el hacinamiento y la insalubridad. Se creaba con todos estos elementos un relato negro sobre el campo que tendría como punto fundamental las historias sobre la represión por la "cuerda india" en la bocamina de La Gamonita en las inmediaciones del recinto. Estos elementos creaban una situación de represión constante que se unía a la labor de reeducación ideológica que trataba de llevar a cabo el Estado franquista ${ }^{11}$ a través

\footnotetext{
${ }^{10}$ Guillermo León Cáceres, Antonio Rodríguez López, et al. “El Campo de Concentración...”, Op. Cit, p. 547.

${ }^{11}$ José Ramón González Cortes, Guillermo León Cáceres, et al. Catálogo de la Exposición 'El sistema de Campos de Concentración franquistas, el campo de concentración de Castuera'. Castuera, AMECADEC, 2009, p. 29.
} 


\section{Sergio González García}

de las misas, los actos y la violencia sistemática que buscaba imponer por el terror nuevos modelos de conducta "correcta"12.

Además, dada la cercanía del campo al casco urbano del municipio, se producía una extensión de la atmósfera de terror más allá de los limites del espacio represivo. La presencia de los presos que iban desde los centros penitenciarios de la Prisión del Partido Judicial del municipio hasta el campo de concentración -como una forma de violencia y humillación más-, las "sacas" falangistas en las inmediaciones del cementerio, las detenciones en el municipio, la violencia sistemática contra los militantes de izquierdas y la presencia de familiares en el camino al campo para poder ver a sus familiares, crearon una atmósfera total de represión, miedo y terror. Se creaba una conexión entre el municipio y el campo que permitía una visibilización de la violencia que se extendía más allá de los lugares de represión ${ }^{13}$. Todos estos elementos marcarían la Castuera de la posguerra donde el franquismo buscaba la eliminación, represión y reeducación del enemigo.

\section{La memoria en Castuera durante el franquismo y la democracia}

El campo fue clausurado en los primeros meses de 1940. Su cierre y desmantelamiento supuso un abandono de los terrenos donde se encontraban las instalaciones llegando a nuestros días como una propiedad privada. A partir de ese momento se produjo un proceso alrededor del relato de lo que había sido el campo de concentración que se articuló sobre dos elementos, por un lado, el miedo inoculado por la estrategia de represión y, por otro, la creación de un relato negro sobre el campo que se vertebró en torno a un proceso de obliteración ${ }^{14}$, impuesto por el franquismo que negaría la existencia del mismo, y la creación de una memoria privatizada que daría lugar a la creación de relatos inconexos, fragmentarios y alejados del espacio público. La búsqueda del franquismo, a partir de un determinado momento, de una conversión de la legitimidad de origen de la victoria en la guerra en una legitimidad de ejercicio reforzó está idea de eliminación de la memoria del campo por considerarse no necesaria para la sociedad. Así, el mismo régimen que en un primer momento proyectó la presencia del campo como forma de extensión del miedo, el castigo y un estado de guerra permanente, pasó posteriormente a eliminar el relato y enclaustrar el mismo al ámbito privado. De esta manera, el lugar no retomó ningún tipo de uso o actividad, algo que contribuiría a la conservación de los restos que todavía se pueden observar en el terreno.

\footnotetext{
12 Antonio López Rodríguez. Cruz, bandera y caudillo..., Op. Cit. p. 274.

13 Antonio López Rodríguez. "Cárceles en el Partido Judicial de Castuera. Antecedentes, contexto y permanencia en el tiempo", Revista de Estudios Extremeños, Vol. LXVII, № 2, Badajoz, 2011, p. 891.

${ }^{14}$ Kenneth Foote. Shadowed Ground. America's Landscapes..., Op. Cit. p. 24.
} 


\section{La 'liberación' del Campo de Concentración de Castuera: rebelarse a través del espacio}

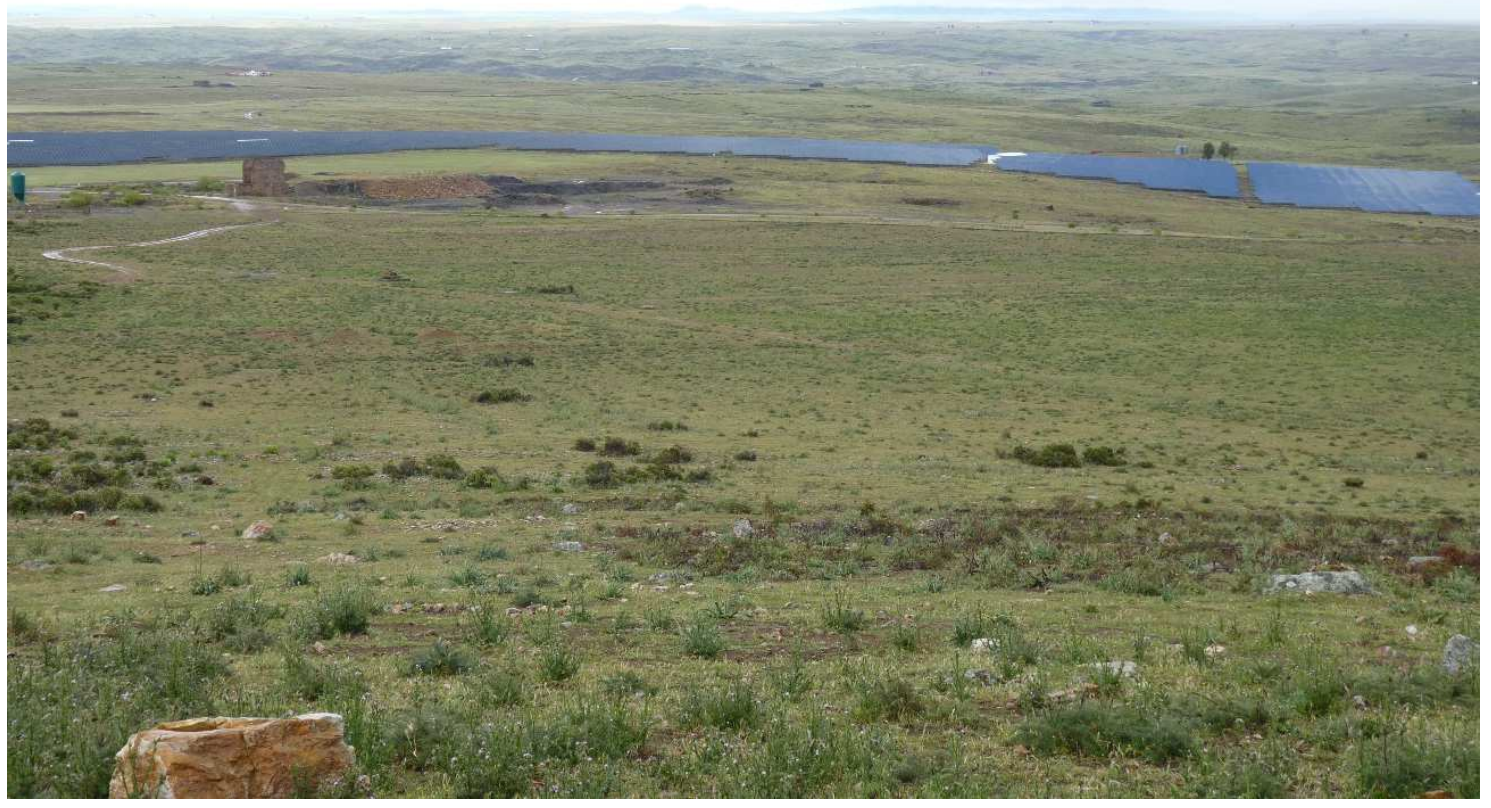

Imagen 1: El terreno que ocupaba el Campo de Concentración de Castuera en la actualidad. Fuente: Autor.

Por lo tanto, no se recordaba el campo porque era algo que no se podía recordar políticamente y, además, era algo vinculado al miedo y al terror creado en los primeros años. La existencia de ese recuerdo, de esa memoria privada y fragmentada sin una articulación social visible, hace evidente que el relato del campo no fue olvidado sino que se obligó a que no fuera recordado.

"Silencio total. La gente sabía que había habido un campo de concentración, que había habido montones de desaparecido de fusilados pero el miedo era latente."15

Se producía entonces un proceso de privatización de la memoria que impedía cualquier tipo de posibilidad de creación de una memoria colectiva al margen de la memoria oficial franquista. El franquismo eliminó cualquier tipo de expresión de la memoria de los vencidos por medio de su erradicación del espacio público y de la imposición de un relato del pasado que impedía la interpelación a lugares o acontecimientos vinculados a una narrativa alternativa reduciendo esta memoria al ámbito privado como único espacio de resistencia generacional ${ }^{16}$. Por lo tanto, el

\footnotetext{
15 Extracto entrevista realizada a informante durante el trabajo de campo de la investigación.

16 Ricard Vinyes. "La memoria del Estado" en Ricar Vinyes (ed.), El Estado y la Memoria: Gobiernos y ciudadanos frente a los traumas de la historia, Barcelona, RBA Libros, 2009.
} 


\section{Sergio González García}

campo de Concentración de Castuera fue sometido a un desconocimiento inducido aunque el miedo impuesto durante la existencia del mismo permanecía.

De alguna manera, no se articulaba o no se organizaba esa memoria, pero no se organizaba esa memoria porque realmente todos los mecanismos estaban desconectados, es decir, la gente vivía, los que habían sufrido la represión en al campo, esa memoria en su casa (...) estamos hablando siempre de una memoria personal, una memoria íntima. ${ }^{17}$

Aún con este intento, la propia presencia de una instalación represiva de estas características, con una intención inicial de reforzar la idea de represión y el terror buscado por el franquismo, propició una reconfiguración del espacio social simbólica y materialmente en Castuera, algo que hizo imposible que el proceso de olvido y silenciamiento fueran totales ${ }^{18}$. El campo de concentración quedaría fijado dentro del imaginario colectivo de posguerra en Castuera. Todo lo cual supone que el intento de eliminación inconcluso y la privatización de la memoria estaban sujetas a una correlación de fuerzas dadas en la posguerra y a una imposición política por parte del nuevo régimen que impedía hacer visible el recuerdo pero no existía un trauma colectivo que socialmente imponía el silencio. No se hablaba porque no se podía hablar y porque existía un miedo real a hacerlo pero existían grietas de la memoria en el ámbito privado que posibilitaban que el relato inconcluso y fragmentario se transmitiera a lo largo del tiempo a través de voces, imágenes, ideas e historias privadas cargadas de emociones, sensaciones y significados subjetivos a nivel local o familiar ${ }^{19}$. Se producía entonces una imposibilidad de construcción de un relato colectivo, una memoria colectiva, dentro de un grupo porque estos elementos estaban desconectados, aislados y no podían formar un grupo autoreconocido como tal en un espacio público dominado por el franquismo. Estas grietas de la memoria, esta posibilidad de transmisión a un nivel privado, la existencia de ese imaginario de posguerra vinculado al campo e, incluso, los restos del mismo y las huellas materiales de la represión, supusieron la permanencia de remanentes ${ }^{20}$ que hicieron imposible que el franquismo pudiera completar ese proceso de obliteración.

Esta lógica, que proyectó el miedo y la represión en un primer momento a todos los rincones del cuerpo social y que posteriormente intentó eliminar cualquier tipo de referencia al campo y a su propia existencia para proyectar otro tipo relato en el municipio, no renunció a producir un espacio en función de unos objetivos políticos, a saber, la reconstrucción de la memoria, la eliminación del relato histórico opuesto y la creación de un nuevo discurso en función de un nuevo relato, unos

\footnotetext{
${ }^{17}$ Extracto entrevista realizada a informante durante el trabajo de campo de la investigación.

18 Pamela Colombo. "Espacio y desaparición: los campos de concentración en Argentina". Isegoría, Revista de Filosofía Moral y Política, №45, 2011, p.639.

${ }_{19}$ Francisco Ferrándiz. El pasado bajo tierra. Exhumaciones contemporáneas de la Guerra Civil. Barcelona, Anthropos, 2014, p. 87-88.

${ }^{20}$ Karen Till. "Urban remnants: Place, Memory and Artistic practice in Berlín and Bogotá". Encounters, №1, 2010, p. 77.
} 


\section{La 'liberación' del Campo de Concentración de Castuera: rebelarse a través del espacio}

nuevos valores y una ideas políticas concretas. Así, en todo el territorio estatal y, también, en Castuera, se proyectó un espacio cargado de símbolos y lugares que "cumplían una función clave en el proceso de socialización política y en los intentos de legitimación del poder"21. Un espacio que se concebía para imponer una determinada moral y unas formas de uso a través de conmemoraciones, monumentos, cruces, memoriales, cambios en el nombre de las calles,... Un espacio representado en base a una intencionalidad política marcada. Así en Castuera se erigió un monumento a los "Caídos por Dios y por España” formado por una cruz y una placa colocadas en la plaza principal del municipio y en la fachada de la Iglesia ${ }^{22}$. Se creaba así un espacio sacralizado por medio de marcas perdurables alrededor de las que se celebraban conmemoraciones y ceremonias a través de las que se proyectaban los valores franquistas y la identidad nacionalcatólica ${ }^{23}$. Una santificación que creaba una conmemoración de buscaba simbolizar que "las víctimas morían por una causa y la causa, más que las víctimas, estimula la santificación"24. De esta manera, con los cambios físicos, la ocupación simbólica y el dominio del relato que se buscaba imponer, la apropiación del espacio público por parte del relato de los vencedores fue total. Se concebía un espacio basado en la sacralización del franquismo, cuyo ejemplo más efectivo era el monumento de homenaje -la cruz y la placa-, y el silenciamiento de todo lo relacionado con el bando derrotado, simbolizado en el abandono y eliminación del relato de la represión y del campo de concentración. Se seleccionaba así qué memoria y por medio de qué representación podía aparecer en el espacio público de Castuera. De esta manera se hicieron constantes los homenajes y las conmemoraciones en el monumento a los caídos, se fijó como celebración la toma del municipio por los franquistas, se realizaron desfiles y se utilizó el espacio público como lugar de escarnio y humillación de los presos que eran conducidos al campo ${ }^{25}$. Todo este conjunto de prácticas configuraban un espacio público articulado en torno a la división entre vencedores y vencidos, entre sacralización y represión. Así, el espacio público quedó simbólicamente privatizado en manos de un único grupo con capacidad efectiva de representarlo y expresar una única memoria que permitía su vertebración identitaria, configurándose así una memoria excluyente ${ }^{26}$. Por lo tanto, un elemento central en el conflicto posterior por la recuperación de la memoria del campo sería la posibilidad de visibiliazación de los relatos silenciados y de sus lugares

\footnotetext{
21 Paloma Aguilar Fernández. Políticas de la memoria y memorias de la política. Madrid, Alianza Editorial, 2008, p. 145.

${ }^{22}$ Guillermo León Cáceres, Antonio Rodríguez López, et al. “El Campo de Concentración...”, Op. Cit, p. 554.

23 Zira Box Varela. La fundación de un régimen. La construcción simbólica del franquismo. Tesis de Doctorado. Madrid. Universidad Complutense de Madrid. 2008.

${ }^{24}$ Kenneth Foote. Shadowed Ground. America's Landscapes..., Op. Cit. p. 10.

25 Guillermo León Cáceres, Antonio Rodríguez López, et al. “El Campo de Concentración...”, Op. Cit, p. 552.

${ }^{26}$ Andrés Alberto Scagliola Díaz. "Cambio en las políticas públicas de la memoria en Cataluña: el pasado como problema”. Entelequía. Revista Interdisciplinar, № 7, 2008, p. 307.
} 
emblemáticos. Estas actuaciones permiten analizar la importancia de la correlación de fuerzas y las relaciones de poder en la construcción de la memoria política y la producción del espacio.

... a los familiares de los izquierdistas asesinados no se les toleraba expresar su dolor en el espacio público (...) no se podían poner monumentos de homenaje como hacían 'los otros'27.

La llegada de la etapa democrática no alteró esta situación y la memoria de la represión tuvo que esperar hasta 2005 para aparecer en el espacio público en forma de primer homenaje a las víctimas del campo de concentración. No se produjo en el municipio ningún tipo de movilización social ni política institucional de recuperación del relato silenciado. El pacto transicional no incluyó un cuestionamiento de la memoria de la guerra civil y la dictadura aunque, según Paloma Aguilar, el recuerdo de la contienda sí estaba presente en forma de "nunca más una guerra" 28 motivando la ausencia de cualquier política pública de recuperación o reparación. En el caso de Castuera, el análisis de la realidad del municipio muestra la permanencia de ese relato vinculado al miedo y el mantenimiento del discurso construido durante el franquismo en forma de permanencia de lugares, nombres de calles, olvido del campo de concentración y memoria privatizada. Tras el proceso de democratización se habría impuesto una buena memoria no conflictiva basada en el consenso, la equiparación y el mito de la transición ejemplar. Así, la democracia "se limitó a decretar socialmente superado cualquier pasado conflictivo, cualquier pasado de confrontación"29 que supondría, en municipios como el estudiado, que en el espacio público se siguiera imponiendo la memoria de los vencedores y las víctimas quedaran fuera de cualquier tipo de reconocimiento.

Entonces tampoco invita a que, bueno, se exprese en el espacio público todo ese sentimiento y que se recuerde en el espacio público a la víctima. ${ }^{30}$

Pilar Calveiro analiza que los campos de concentración sólo son posibles en sociedades que deciden "no ver" 31 , y en el caso de Castuera el período democrático supuso la elección de mantener al margen del relato del pueblo la existencia del campo y la decisión de "vivir de espaldas a ese testimonio"32 no trasladando esa parte de la historia por los mecanismos de socialización pública básicos manteniendo ese "desconocimiento inducido" 33 . No se hacía referencia al campo a ningún nivel del ámbito público. Silencio, privatización y actuaciones institucionales

\footnotetext{
${ }^{27}$ Extracto entrevista realizada a informante durante el trabajo de campo de la investigación.

${ }^{28}$ Paloma Aguilar Fernández. Políticas de la memoria y..., Op. Cit. p. 416.

${ }^{29}$ Ricard Vinyes. “La memoria del...”, Op. Cit., p. 35.

${ }^{30}$ Extracto entrevista realizada a informante durante el trabajo de campo de la investigación.

${ }^{31}$ Pilar Calveiro. Poder y desaparición. Buenos Aires, Calihue, 1998, p. 26.

${ }^{32}$ Extracto entrevista realizada a informante durante el trabajo de campo de la investigación.

${ }^{33}$ Extracto entrevista realizada a informante durante el trabajo de campo de la investigación.
} 


\section{La 'liberación' del Campo de Concentración de Castuera: rebelarse a través del espacio}

estuvieron marcadas por el clima de consenso y pacificación que serían la causa principal de la ausencia de cualquier tipo de homenaje hasta el año 2005. A nivel institucional el Ayuntamiento, gobernado por el PSOE, únicamente realizó, en todos sus años de hegemonía en el gobierno municipal, ligeras modificaciones del espacio público heredado del franquismo. La cruz a los "caídos" fue trasladada del municipio a la puerta del cementerio cuando en 1990 se realizó la modificación de la plaza con la intención de configurar el espacio público acorde a los valores de reconciliación y consenso de la transición para "la superación plena de pequeños o grandes conflictos de división de las llamadas dos Españas"34. Traslado visto como acción administrativa que no suponía un vaciamiento del significado del monumento sino que tenía como intención "un deber moral para la buena convivencia de los ciudadanos"35. También se eliminaron algunas calles de origen franquista pero se mantuvieron otras creando un callejero donde se producía una yuxtaposición y convivencia de nombres provenientes de relatos diferenciados creando un espacio basado en las ideas de consenso, pacificación y reconciliación. De esta manera, se mantenía la calle Mártires de la Cruzada conviviendo con la calle de la Constitución o Miguel Hernández o estatuas erigidas a Salvador Allende con esculturas de homenaje a las Fuerzas Aéreas ${ }^{36}$.

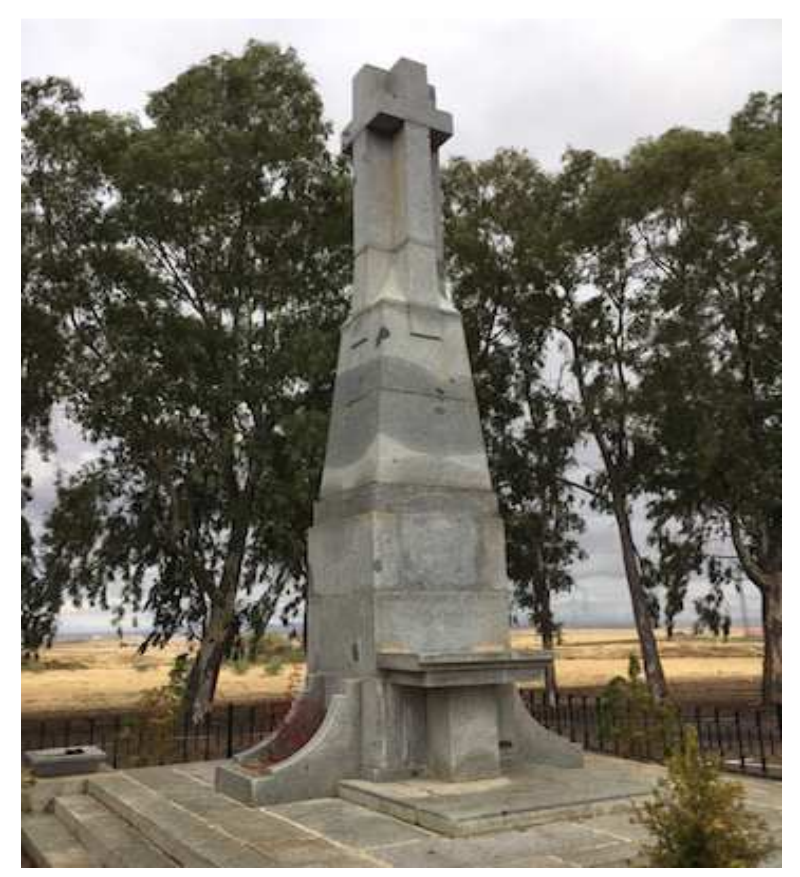

Imagen 2: Cruz de homenaje a los "caídos" en la puerta del cementerio municipal. Fuente: Autor.

\footnotetext{
${ }^{34}$ Acta del Pleno del Ayuntamiento de Castuera del 31 de Marzo de 1995.

35 Ricard Vinyes. "La memoria del...", Op. Cit., p. 25.

36 En el año 2001, el gobierno municipal del PSOE erigió en una de las rotondas de entrada al municipio una escultura de homenaje a las Fuerzas Áreas en forma de un avión de combate real situado en una peana. Esta decisión fue muy controvertida en el municipio puesto que identificaba al pueblo con la presencia de un símbolo bélico. El avión fue retirado en el año 2012 por el nuevo gobierno municipal del Partido Popular (PP) a petición de Izquierda Unidad (IU).
} 


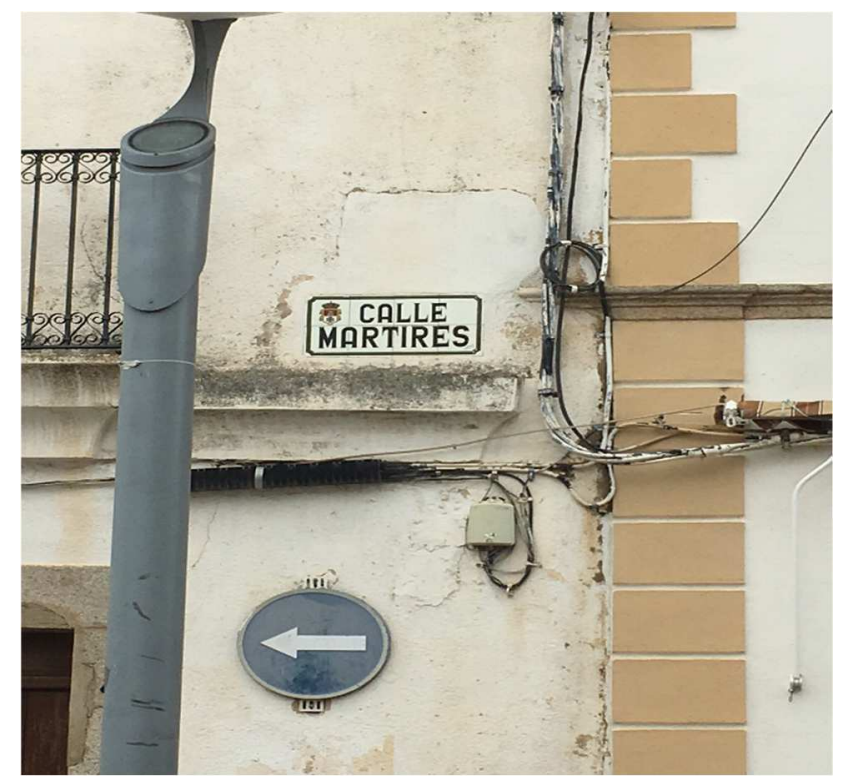

Imagen 3: Calle Mártires (anteriormente Mártires de la Cruzada). Fuente: Autor.

Se mantenía todavía fuera del espacio público cualquier referencia al pasado represivo y, debido al mantenimiento de los lugares y su significado, persistía la impunidad del pasado dictatorial. Se concebía un espacio donde el relato del pasado franquista sólo era omitido -trasladado de lugar- y no eliminado en la búsqueda de la pacificación y el consenso. El primer acto de conmemoración y recuperación del pasado del campo en 2005 fue fruto de un proceso de varios años y diversos acontecimientos que conformaron una verdadera revuelta de la memoria ${ }^{37}$ que permitió la aparición en el espacio público de ese relato privatizado. Momento en el que esos relatos inconexos y fragmentados pudieron autoreconocerse como un grupo con una memoria colectiva común que ahora se hacía visible. Se produciría, a partir de ese momento, esa unión entre memoria y grupo que anunciaba Maurice Halbwachs en su obra ${ }^{38}$.

Los acontecimientos que habían marcado esa revuelta de la memoria comenzaron con la aparición a nivel estatal en el año 2000 de la Asociación para la Recuperación de la Memoria Histórica que había introducido la recuperación del pasado represivo en la agenda pública e iniciado un debate que movía los pactos de la transición más allá de la idea de la reconciliación ${ }^{39}$. A nivel local, en Castuera, la emisión del documental "La pesadilla de Castuera" en un programa de la televisión pública marcó un antes y un después en el mantenimiento de ese silencio impuesto

\footnotetext{
37 Manuel Loff. "Estado, democracia e memoria: políticas públicas e batalhas pela memoria da ditadura portuguesa (1974-2014)" en M. Loff, F. Piedade y L. Castro Soutelo (eds.), Ditaduras e revoluçao. Democracia e políticas da memoria, Coimbra, Almedina, 2015, p. 87.

38 Maurice Halbwachs. La memoria colectiva, Zaragoza, Prensas Universitarias de Zaragoza, 2004 (1978).

${ }^{39}$ Georgina Blakeley. "Politics as usual? The trials and tribulations of the law of historical memory in Spain”, Entelequia. Revista Interdisciplinar, № 7, 2008, p. 316
} 


\section{La 'liberación’ del Campo de Concentración de Castuera: rebelarse a través del espacio}

en el municipio. Además, la aparición de estudios académicos que se centraban en la represión en Extremadura y que incluían análisis del campo de concentración también permitieron la apertura del debate y "contribuyeron a la movilización de ex prisioneros, familiares, historiadores y organizaciones sociopolíticas" 40 . Todo esto unido a, como hemos mencionado anteriormente, la existencia de grietas de la memoria que posibilitaron que ciertos relatos de la represión y la existencia del campo fueran transmitidos de manera velada, inconclusa o a través de objetos que actuaban como repositorios de la memoria ${ }^{41}$.

...pues yo lo conocía a través de mecanismos informales, de mi propia curiosidad y del antecedente familiar, que tenía pues el gusanillo, ya me lo había, mi abuela materna, me lo había ya sembrado, ese semilla por el interés por la represión de mi propio abuelo y de lo que había sucedido más allá42.

En Abril de 2005, desde la asamblea local de Izquierda Unida, se convocaron unas jornadas republicanas que terminaron con un homenaje en los terrenos del campo de concentración. A partir de ese momento esa contramemoria apareció de forma visible en el espacio publico configurando un grupo cohesionado que demandaba su recuperación y que establecía un contraespacio que señalaba los lugares emblemáticos del pueblo asociados a la represión y los convertía en lugares de homenaje. Un forma de entender el espacio desde su experiencia que entraba en conflicto con la representación institucional del municipio basada en el consenso, la pacificación y la proyección del mismo asociado a la agricultura, la ganadería y la artesanía. Esta práctica iniciaría la celebración de homenajes periódicos que resignificarían el campo de concentración como lugar convocante de homenaje, recuperación y no vinculado al silencio y la represión. Se hacía visible así el conflicto entre una concepción y una vivencia del espacio que dotaban de significados diferenciados a estos lugares emblemáticos y a los elementos que el municipio debía proyectar.

\section{La marcha de homenaje como práctica de rebeldía}

La marcha de homenaje recorre el municipio desde la plaza de España hasta los terrenos del campo donde se realiza el izado de una bandera republicana, se lee un manifiesto y se dejan flores en forma de conmemoración en la peana donde se ubicaba la cruz del patio. El recorrido por los más de dos kilómetros se realiza en ambiente serio donde proliferan banderas y símbolos de partidos de izquierdas y elementos vinculados al bando republicano. La marcha también se convierte en una

\footnotetext{
40 Guillermo León Cáceres, Antonio Rodríguez López, et al. “El Campo de Concentración...”, Op. Cit, p. 549.

41 Francisco Ferrándiz. El pasado bajo tierra..., Op. Cit., p. 88.

42 Extracto entrevista realizada a informante durante el trabajo de campo de la investigación.
} 


\section{Sergio González García}

suerte de manifestación que exige la recuperación de la memoria republicana y las reclamaciones del movimiento memorialista de verdad, justicia y reparación. El punto de partida se ubica en la plaza por ser el punto donde se encontraba la Prisión de Partido y por lo tanto la marcha recorre el mismo trayecto que realizaba la cuerda de presos republicanos al finalizar la contienda. Además, se pasa por delante del cementerio que queda también simbolizado como un lugar vinculado al relato de la represión en el municipio.

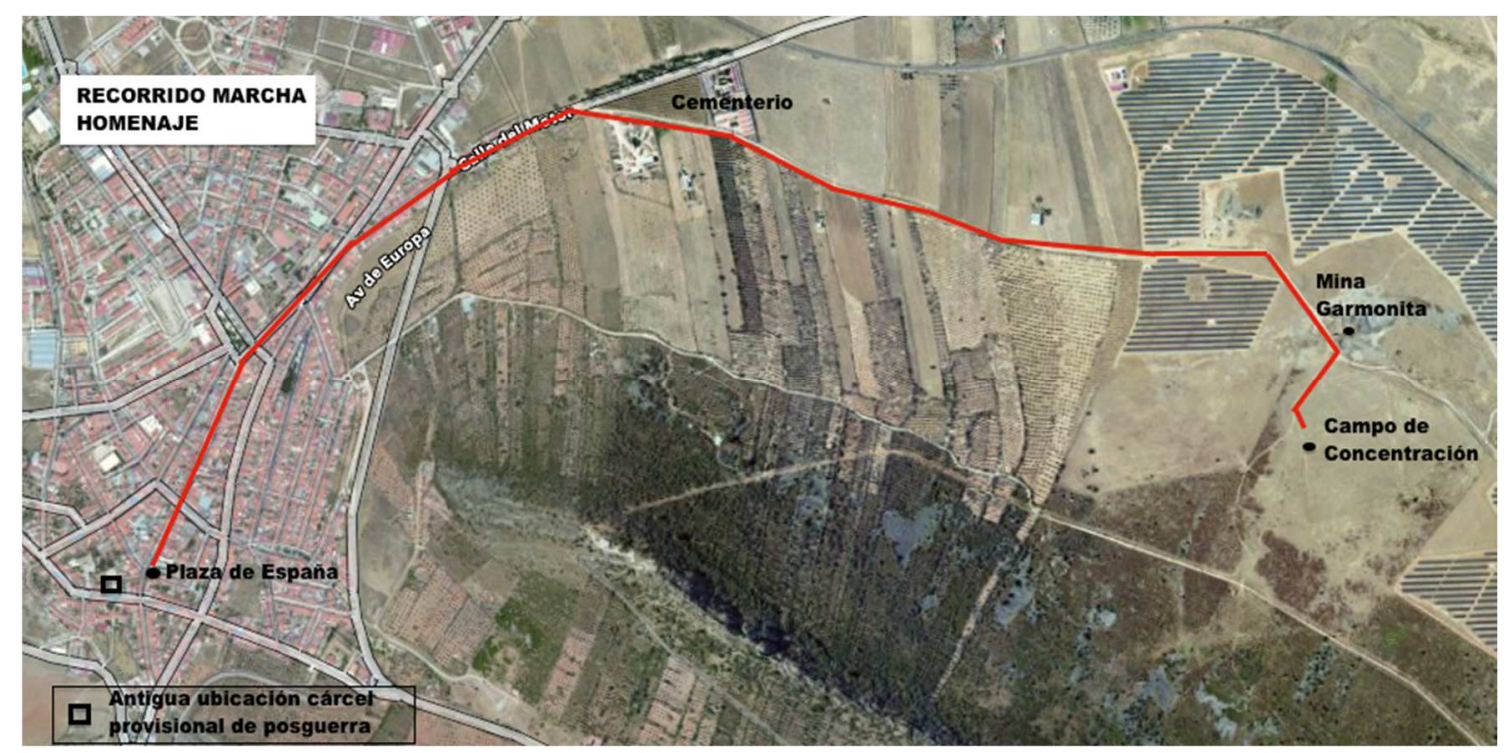

Mapa 3: Mapa del recorrido de la marcha de homenaje. Fuente: Elaboración propia a partir de imágenes obtenidas de Google Maps (@2016 Google, Inst. Geogr. Nacional).

La marcha de homenaje tendría dos consecuencias directas inmediatas. Primero, la visibilización de la memoria privatizada que aparecía ahora en el espacio público en forma de una memoria social contestataria. Visibilidad que iría asociada a la necesidad de difusión y pedagogía que daría lugar a la proliferación de recursos didácticos sobre el campo ${ }^{43}$. La segunda de estas consecuencias fue la resignificación y reapropiación del campo mediante su "liberación". La lectura del manifiesto y el izado de la bandera republicana suponían un proceso de apropiación simbólica que señalizaba el campo como un lugar de conmemoración republicana, es decir, un lugar de memoria que permitía hacer público el recuerdo. El campo dejaba de estar asociado a la represión y al olvido y quedaba vinculado a la conmemoración, el homenaje y la reparación. Ya no era un lugar franquista, era un lugar republicano de homenaje. De esta manera se iban sedimentando en el campo distintas capas de significado.

Las marchas permitían crear una comunidad, un grupo de pertenencia, con pasados comunes vinculados a la represión en el campo, tanto personal como de

\footnotetext{
${ }^{43}$ José Ramón González Cortes. Unidad didáctica. El sistema de campos de concentración franquista. El campo de concentración de Castuera, Mérida, 2011.
} 


\section{La 'liberación' del Campo de Concentración de Castuera: rebelarse a través del espacio}

familiares. En los actos aparecían personas con fotos de familiares que contaban en público sus relatos permitiendo que esa memoria individual que había estado circunscrita al ámbito doméstico se convirtiera en una memoria social ${ }^{44}$ que portaba experiencias que trascendían el horizonte temporal del individuo por ser un relato que se transmitía dentro de un colectivo. Con el conjunto de acciones que la asociación AMECADEC, fundada en 2006, puso en acción (marcha, jornadas, exposición, seminarios,...), el conjunto de valores y los aspectos fundamentales de las reivindicaciones de este grupo aparecieron en el espacio público de forma permanente. Así, se configuraba un espacio vivido, un espacio de representación como lugar de la resistencia como anunciaba Lefebvre ${ }^{45}$, que señalaba lugares de homenaje, reivindicaba políticamente la memoria de la II República y de los vencidos y reclamaba la recuperación institucional de este relato del pasado impugnando la narrativa de equiparación, consenso y superación. La marcha permitía la materialización y localización de ese espacio vivido que señalaba puntos simbólicos a través del recorrido, los cuales sacaban a la luz un relato silenciado, una memoria social subalterna, que por medio de la propia práctica se transmitía. Se creaba, por lo tanto, un nexo intergeneracional a través de la práctica.

Dwyer y Alderman exponían que los lugares de memoria se podían analizar desde tres metáforas que marcan los elementos que se destacan en el análisis, la metáfora del texto, la arena y la performance ${ }^{46}$. Estableciendo una relación entre estas tres formas de acercarse a la realidad de los lugares de memoria, en el caso de Castuera, con la marcha de homenaje anual, se ponía de relieve que el campo habría sido resignificado por medio de una reescritura de los valores y el relato del pasado que proyectaba (texto) donde entraban en conflicto distintas interpretaciones y significados (arena), los cuales, por último, se ponían en juego a través de diversas prácticas (performance). Por lo tanto, esta performatividad resultaba básica, en nuestro análisis, para entender cómo se hacía visible y se materializaba la resistencia al discurso oficial y a la forma que se producía el espacio en el municipio.

\footnotetext{
${ }^{44}$ Aleida Assmann. "Memory, individual and collective" en R. Goodin y C. Tilly (eds), The Oxford Handbook of Contextual Political Analysis, New York, Oxford University Press, 2006, p.213-215.

${ }^{45}$ Henri Lefebvre. La producción del..., Op. Cit. p. 98-100.

46 Owen Dwyer y Derek Alderman. "Memorial landscapes: analityc question and metaphors", GeoJurnal, № 73, 2008, p. 101-138.
} 


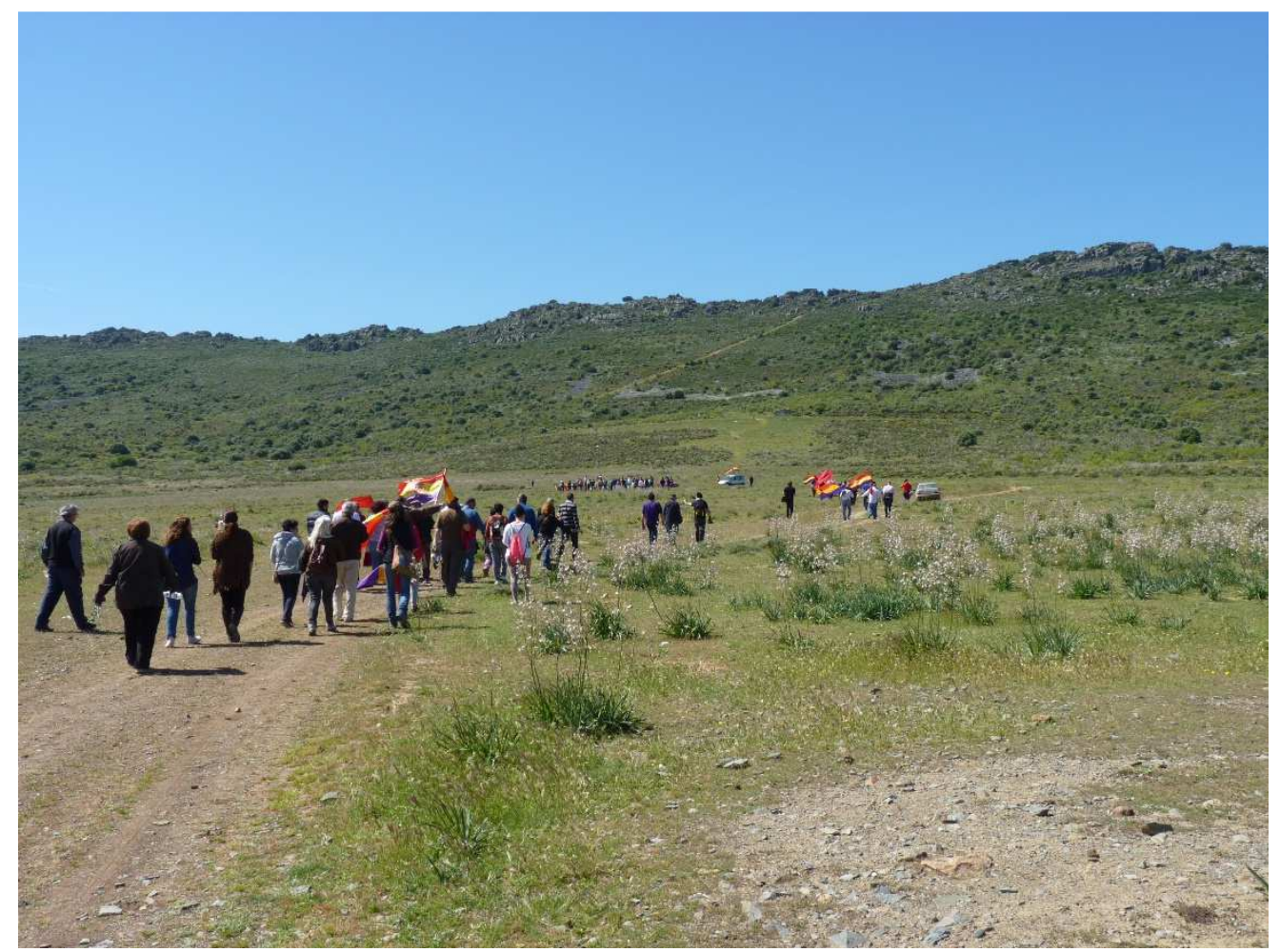

Imagen 4: Marcha de homenaje a su llegada al campo de concentración. Fuente: Autor.

La marcha no sólo resignificaba el campo sino también señalaba y marcaba como lugares emblemáticos otra serie de localizaciones que estaban vinculadas a la represión, por ejemplo, el cementerio y la mina de La Gamonita. Así, a través de acciones como pintadas que pedían el recuerdo y la ruptura con el mensaje de conciliación, o como la acción "flores contra el olvido" que marcaba con flores estos lugares, se conseguía una resignificación y una reapropiación en el sentido de crear el "habitar" lefebvriano ${ }^{47}$ adaptándolo y usándolo para crear esos lugares y centros afectivos, es decir, para "verter sobre él la afectividad del usuario"48, en este caso el grupo militante.

A través de estas acciones performativas se generaban situaciones que tenían como consecuencias fundamental la ruptura de la normatividad impuesta sobre el espacio $^{49}$, una normatividad que se expresaba a través del reconocimiento patrimonial institucional de lugares como el Museo del Turrón, la Iglesia parroquial, las casas más representativas de la arquitectura rural, la Ermita de San Benito y algunos yacimientos arqueológicos, que proyectaban un imaginario del municipio alejado de cualquier recuerdo a la memoria de la represión y la guerra. Así, con el reconocimiento como Bien de Interés Cultural del campo de concentración por parte de la Junta de Extremadura en 2009 se generaba una política de conservación que

\footnotetext{
${ }^{47}$ Henri Lefebvre. La producción del..., Op. Cit. p. 100.

48 Emilio Martínez Gutiérrez. "Ciudad, espacio y cotidianidad en el pensamiento de Henri Lefebvre" en Henri Lefebvre, La producción del espacio, Madrid, Capitán Swing Libros, 2013, p. 45.

49 Manuel Trufó. "Descentralizar la memoria. Dos lógicas de intervención sobre el espacio urbano en la ciudad de Buenos Aires”, Universitas Humanística, №70, 2010, p. 125.
} 


\section{La 'liberación’ del Campo de Concentración de Castuera: rebelarse a través del espacio}

no implicaba ningún tipo de homenaje. Por lo tanto, aun con esta conservación formal el campo sólo obtuvo una reconocimiento patrimonial que lo situaba dentro de una figura de planeamiento urbanístico que no generaba ningún tipo de reconocimiento simbólico institucional. Al no existir una práctica simbólica y conmemorativa oficial el campo simplemente quedaba vinculado a una parcela más con un grado de protección institucional dentro de las distintas figuras de planeamiento urbanístico que quedaban relegadas al ámbito técnico y formal.

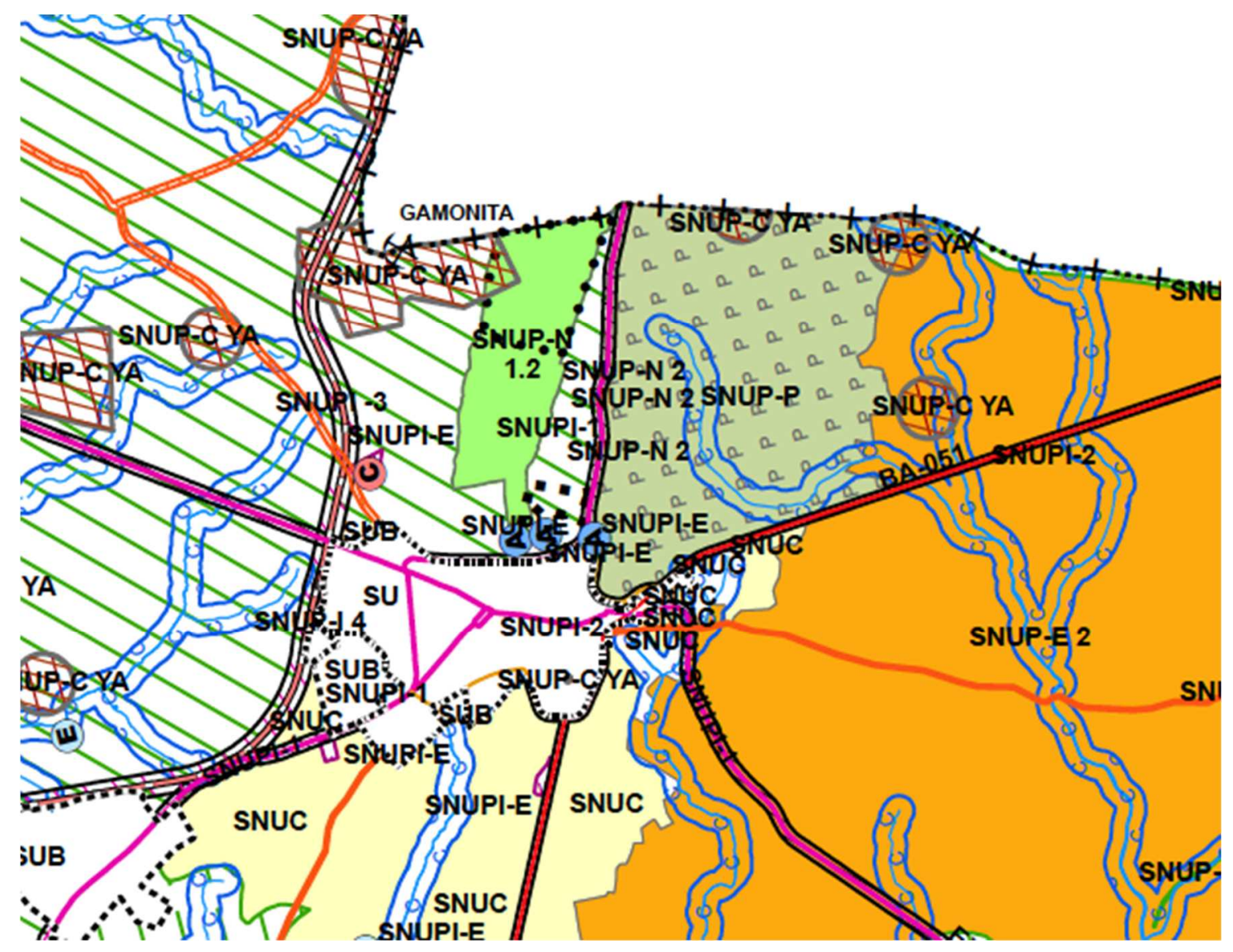

Mapa 4: Plano de ordenación urbanística del área que comprende el campo de concentración del Castuera donde se aprecian las distintas categorías urbanas de las parcelas. Fuente: Plan Municipal de Castuera. Tomo III Planos de Ordenación Urbana. Plano OE.10 Clasificación del suelo. Obtenido de la página http://www.castuera.es/plantilla.php?enlace=planos ordenación

No existía ni una señalización patrimonial clara, visible y accesible por parte del Ayuntamiento ni ningún tipo de acción conmemorativa institucionalizada. Por lo tanto, la ausencia de actos performativos por parte de las instituciones, en forma de homenaje o conmemoración, impedían que de la protección se pasara a la creación de una memoria del campo que pudiera trascender del grupo de familiaresmilitantes y que tuviera un reconocimiento y proyección pública a nivel oficial. La memoria oficial se mantenía dentro de la idea de neutralidad, equiparación y pacificación puesto que el reconocimiento no pasaba del nivel administrativo. Sólo 


\section{Sergio González García}

la marcha organizada por AMECADEC y los familiares rompía esta lógica del "museo sincrético" del que hablaba Vinyes para la expresión de la memoria en la etapa democrática donde se mantenía la idea de conciliación, reconciliación y equiparación por el uso ahistórico del pasado ${ }^{50}$.

De esta manera, la recuperación informal del campo estaba sujeta a las acciones y reclamaciones de AMECADEC, los familiares y el grupo de militantes memorialistas. Un grupo que tenía como objetivos la reparación simbólica, el homenaje, el apoyo a los familiares, la recuperación de la memoria y la proyección del campo de concentración y de los lugares vinculados a la represión en Castuera como elementos pedagógicos en la defensa de los Derechos Humanos.

...que esto trasciende, que esto trasciende el plano local, también el comarcal, el provincial, el regional y, yo me atrevería a decir, el nacional, porque los campos de concentración, porque un campo de concentración es un lugar donde conmemorar y promover los valores democráticos. ${ }^{51}$

Estos se convierten en los objetivos fundamentales de la lucha por la visibilización y resignificación del campo. En función de esto, la marcha, como práctica que se rebela contra un statu quo que mantiene oculta la memoria represiva y que configura un espacio que proyecta los valores de la pacificación y la neutralidad, se convierte en el eje en torno al cual gira toda la plasmación de ese conjunto de significados y discursos sobre el campo. Una práctica que constituye la materialización de la existencia de ese espacio vivido militante y de familiares donde el campo se convierte en un lugar convocante a señalizar y recuperar. La marcha aparece como elemento diferencial que permite contrastar dos formas de relacionarse con el pasado represivo. Por un lado el simple reconocimiento administrativo que no implica ningún tipo de recuperación memorial y mantiene un discurso pacificado del espacio público, y por otro lado, la performatividad asociada a la conmemoración y la recuperación de la memoria con la intención de proyectar Castuera como lugar de recuperación del pasado, de homenaje y de defensa de los Derechos Humanos. Un homenaje que, como se analiza, es eminentemente performativo y se basa en la señalización y la reapropiación.

La marcha es, de esta manera, una práctica que permite ver la apropiación total del espacio público al suponer un conjunto de gente ocupando el mismo durante el recorrido de un punto a otro. Esta ocupación dibuja y reactualiza un imaginario colectivo donde distintos puntos del espacio urbano quedan conectados enmendando el uso normativo del mismo ${ }^{52}$. Así, no sólo el punto de partida y el de llegada quedan vinculados a los presos y la represión sino que todo el recorrido queda vinculado con el pasado, el cementerio con la existencia de las "sacas"

\footnotetext{
50 Ricard Vinyes. "Hacer las paces. Sobre símbolos y monumentos: la construcción del museo sincrético", Clepsidra. Revista Interdisciplinaria de estudios sobre memoria. № 2, 2014, p. 18.

51 Extracto entrevista realizada a informante durante el trabajo de campo de la investigación.

52 Laura Cecilia Mombello. "Neuquén, la memoria peregrina" en Elizabeth Jelin (ed), Monumentos, memoriales y marcas territoriales, Madrid, s.XXI, 2003, p. 152
} 


\section{La 'liberación’ del Campo de Concentración de Castuera: rebelarse a través del espacio}

falangistas y la necesidad de honrar a los asesinados, la mina de La Gamonita con el recuerdo de los que allí murieron y la peana de la cruz con el izado de la bandera republicana y la "liberación" del campo para conmemorar.

Un elemento fundamental reside en entender cómo la memoria se recupera a través de la perfomatividad que representa la marcha y que a su vez evidencia la existencia de una forma alternativa de entender el espacio público del municipio. La marcha pone de manifiesto dos tipos de memorias, por un lado aquella que se pretende visibilizar y reparar, es decir, la memoria silenciada de la represión vinculada al bando derrotado, y por otro lado, la memoria asociada con la propia marcha como práctica ritual anual que permite el autoreconocimiento entre los actores y la articulación de una identidad colectiva, una memoria peregrina ${ }^{53}$. El recuerdo de las marchas pasadas, como forma propia de reivindicación, como acontecimiento repetido de homenaje, que hunde sus raíces en el recuerdo del primer homenaje en el año 2005 como suceso fundacional, catártico y de revelación de lo que estaba silenciado, se convierte en una práctica que define al grupo y permite la reactivación de la memoria del pasado ${ }^{54}$. Algo que se consigue con la presencia de las mismas personas y los mismos símbolos año tras año lo cual permite la autoidentificación del colectivo a lo largo del tiempo. La marcha, por lo tanto, funciona como una práctica espacial y de memoria que gracias a su periodicidad permite proyectar a futuro la recuperación del relato de la represión y al colectivo que la reclama. Esto añade capas de significado a la memoria y establece la forma hegemónica de conmemoración, en este caso no por medio de placas y monumentos, sino por la puesta en práctica de una performance. Entonces, el espacio público de Castuera no sólo es apropiado por el colectivo sino que también éste lo construye, lo dota de significados y lo proyecta a futuro.

\section{Conclusiones: la práctica como materialización del conflicto}

La investigación y un análisis de la práctica arroja una primera idea a destacar de este artículo. Con la marcha, la memoria silenciada, que transporta otra forma de entender y vivir el espacio público señalando sus lugares emblemáticos y la representación que quieren proyectar, consiguió atribuir un significado conmemorativo al campo que la concepción oficial del espacio por parte de las políticas institucionales no le daban. La marcha se convirtió así en la expresión más clara del conflicto entre la forma de mirar al pasado oficial y la memoria subalterna impugnadora de ese relato las cuales producían formas de entender y usar el espacio público diferenciadas. Así, las acciones concretas como la marcha, las pintadas, las "flores contra el olvido" y las visitas guiadas al campo se convirtieron en materializaciones específicas de una forma de vivir el espacio en la experiencia diaria que impugnaba la concepción oficial.

\footnotetext{
${ }^{53}$ Laura Cecilia Mombello. “Neuquén, la memoria peregrina..., Op. Cit., p. 151.

54 Ídem, p. 161.
} 


\section{Sergio González García}

La marcha conseguía una actualización constante del pasado y una vertebración continuada del grupo que se reconocía y se identificaba como un colectivo cohesionado a través de la práctica. Al núcleo de la asociación AMECADEC y los familiares se le unían militantes memorialistas y otros ciudadanos de la comarca que tenían relatos familiares vinculados al campo de concentración. En la marcha, ese grupo disperso, se encontraba y se vinculaba de nuevo a una reclamación común. Un grupo con una memoria colectiva y una práctica que la hacía visible y les permitía rebelarse a través del espacio.

\section{Bibliografía}

Andrés Alberto Scagliola Díaz. "Cambio en las políticas públicas de la memoria en Cataluña: el pasado como problema”. Entelequía. Revista Interdisciplinar, № 7, 2008, p. 301-313.

Antonio López Rodríguez. Cruz, bandera y caudillo. El Campo de Concentración de Castuera. Badajoz, CEDER-La Serena, 2006

Antonio López Rodríguez. "Cárceles en el Partido Judicial de Castuera. Antecedentes, contexto y permanencia en el tiempo", Revista de Estudios Extremeños, Vol. LXVII, № 2, Badajoz, 2011, p. 837-908.

Aleida Assmann. "Memory, individual and collective" en R. Goodin y C. Tilly (eds.), The Oxford Handbook of Contextual Political Analysis, New York, Oxford University Press, 2006.

Emilio Martínez Gutiérrez. "Ciudad, espacio y cotidianidad en el pensamiento de Henri Lefebvre" en Henri Lefebvre, La producción del espacio, Madrid, Capitán Swing Libros, 2013.

Enzo Traverso. El pasado, instrucciones de uso. Historia, memoria, política. MadridBarcelona, Marcial Pons, 2007.

Erik Meyer. "Memory and politics" en A. Erll y A. Nünning (eds.), Memory Studies: And International and Interdisciplinary Handbook, Berlín, Walter de Gruyter, 2008,

Francisco Ferrándiz. El pasado bajo tierra. Exhumaciones contemporáneas de la Guerra Civil. Barcelona, Anthropos, 2014.

Georgina Blakeley. "Politics as usual? The trials and tribulations of the law of historical memory in Spain”, Entelequia. Revista Interdisciplinar, № 7, 2008, p. 315330.

Guillermo León Cáceres, Antonio Rodríguez López, et al. "El Campo de Concentración de Castuera: del olvido forzado a lugar de memoria y recurso 


\section{La 'liberación' del Campo de Concentración de Castuera: rebelarse a través del espacio}

didáctico". Revista de Estudios Extremeños, Vol. LXVII, № 2, Badajoz, 2011, p. 527594.

Henri Lefebvre. La producción del espacio. Madrid, Capitán Swing Libros, 2013 (1974).

José Ramón González Cortes, Guillermo León Cáceres, et al. Catálogo de la Exposición 'El sistema de Campos de Concentración franquistas, el campo de concentración de Castuera'. Castuera, AMECADEC, 2009.

José Ramón González Cortes. Unidad didáctica. El sistema de campos de concentración franquista. El campo de concentración de Castuera, Mérida, 2011.

Karen Till. "Emplacing memory through the city: the New Berlin". GHI Bulletin, №35, 2004

Karen Till. "Urban remnants: Place, Memory and Artistic practice in Berlín and Bogotá”. Encounters, №1, 2010, p. 75-87.

Karen Till. "Places of memory" en J. Agnew, K. Mitchel y G. Toal, A companion of Political Geography, Londres, Blackwell Publishing Company, 2003

Kenneth Foote. Shadowed Ground. America's Landscapes of Violence and Tragedy. Austin (Texas), University of Texas, 1997,

Laura Cecilia Mombello. "Neuquén, la memoria peregrina" en Elizabeth Jelin (ed), Monumentos, memoriales y marcas territoriales, Madrid, s.XXI, 2003,

Manuel Loff. "Estado, democracia e memoria: políticas públicas e batalhas pela memoria da ditadura portuguesa (1974-2014)" en M. Loff, F. Piedade y L. Castro Soutelo (eds.), Ditaduras e revoluçao. Democracia e políticas da memoria, Coímbra, Almedina, 2015.

Manuel Trufó. "Descentralizar la memoria. Dos lógicas de intervención sobre el espacio urbano en la ciudad de Buenos Aires", Universitas Humanística, №70, 2010, p. 119-152.

Maurice Halbwachs. La memoria colectiva, Zaragoza, Prensas Universitarias de Zaragoza, 2004 (1978).

Owen Dwyer y Derek Alderman. "Memorial landscapes: analityc question and metaphors”, GeoJurnal, № 73, 2008, p. 165-178.

Paloma Aguilar Fernández. Políticas de la memoria y memorias de la política. Madrid, Alianza Editorial, 2008.

Pamela Colombo. "Espacio y desaparición: los campos de concentración en Argentina”. Isegoría, Revista de Filosofía Moral y Política, №45, 2011, p. 639-652.

Pilar Calveiro. Poder y desaparición. Buenos Aires, Calihue, 1998. 


\section{Sergio González García}

Ricard Vinyes. "La memoria del Estado" en Ricard Vinyes (ed.), El Estado y la Memoria: Gobiernos y ciudadanos frente a los traumas de la historia, Barcelona, RBA Libros, 2009.

Ricard Vinyes. "Hacer las paces. Sobre símbolos y monumentos: la construcción del museo sincrético", Clepsidra. Revista Interdisciplinaria de estudios sobre memoria, № 2, 2014, p. 12-17.

Zira Box Varela. La fundación de un régimen. La construcción simbólica del franquismo. Tesis de Doctorado. Madrid. Universidad Complutense de Madrid. 2008.

Recibido: 08/09/2017

Evaluado: $27 / 10 / 2017$

Versión Final: 24/12/2017 